\title{
Pharmacokinetic profiles of marbofloxacin following single and repeated oral administration in broiler chickens
}

\author{
Harshad B. Patel, Urvesh D. Patel, Chirag M. Modi, Shaul Ahmed and Shivani L. Solanki \\ Department of Veterinary Pharmacology and Toxicology, College of Veterinary Science and Animal Husbandry, \\ Junagadh Agricultural University, Junagadh-362001, Gujarat, India
}

Received June 23, 2018: Revised August 10, 2018: Accepted August 15, 2018: Published online December 30, 2018

\begin{abstract}
Marbofloxacin is a synthetic, $3^{\text {rd }}$ generation floroquinolone compound, having concentration dependent bactericidal activity. After administration of drugs through oral route, first pass effect or pre-systemic elimination is one of the major factors which results in to reduced bioavailability. The present study was planned to investigate the pharmacokinetics of marbofloxacin, following single $(5 \mathrm{mg} / \mathrm{kg})$ and repeated dose $(5 \mathrm{mg} / \mathrm{kg})$ for 5 days oral administration in broiler chickens. Plasma samples were analyzed for marbofloxacin concentration by HPLC with UV detector. The mean values of absorption half-life $\left(\mathrm{t}_{1 / 2 \mathrm{ka}}\right)$ after single and repeated oral administration were 0.22 \pm 0.04 and $0.34 \pm 0.07 \mathrm{~h}$, respectively and the area under curve (AUC) were $15.11 \pm 2.19$ and $16.49 \pm 1.88 \mu \mathrm{g} . \mathrm{h} / \mathrm{ml}$, respectively. The mean values of volume of distribution at pseudo equilibrium $\mathrm{Vd}_{\text {(area) }}$ were $1.32 \pm 0.10$ and $1.61 \pm 0.21 \mathrm{l} / \mathrm{kg}$, respectively after single and repeated oral administration whereas elimination half-life $\left(\mathrm{t}_{1 / 2 \beta}\right)$ were $4.62 \pm 0.42$ and $5.63 \pm 0.60 \mathrm{~h}$, respectively. The total body clearance $\left(\mathrm{Cl}_{\mathrm{B}}\right)$ and mean residence time (MRT) of drug were not significantly differ after repeated dose oral administration as compared to single dose. The plasma concentrations of $\geq 0.38 \pm 0.06$ and $\geq 0.43 \pm 0.07 \mu \mathrm{g} / \mathrm{ml}$, were maintained up to $12 \mathrm{~h}$ after single and repeated oral administration, respectively which were found to produce sufficient AUC/MIC ${ }_{90}$ and $\mathrm{C}_{\max } / \mathrm{MIC}_{90}$ of $151.10 \mathrm{~h}$ and 20.50 , respectively at $\mathrm{MIC}_{90}$ value of $0.10 \mu \mathrm{g} / \mathrm{ml}$. Thus, marbofloxacin following single and repeated dose oral administration at $5 \mathrm{mg} / \mathrm{kg}$ for 5 days may be effective to eliminate susceptible bacteria in broiler chickens.
\end{abstract}

Key words: Marbofloxacin, single and repeated oral administration, pharmacokinetics, broiler chickens

\section{Introduction}

Development of antimicrobial resistance is an important global concern and there is an utmost requirement of new antimicrobial agent which has diverse chemical properties and mechanism of action (Jinukuti and Giri, 2013). Marbofloxacin, a third generation, fluorinated quinolone compound which is developed for exclusive use against animal bacterial infections (Brown, 1996). Marbofloxacin differs from other fluoroquinolones in chemical structure as presence of an oxadiazine ring, which provides pharmacokinetic advantage such as long elimination half-life (Fitton, 1992). It exhibits bactericidal action by inhibiting bacterial DNA topoisomerases II (gyrase) and IV, and prevents supercoiling of DNA (Drlica and Zhao, 1997). It has also shown a significant post antibiotic effect (PAE) for both Gram-positive and Gram-negative bacteria and it can kill bacteria during both stationary and growth phase of bacterial multiplication (Plumb, 2015). Important pharmacokinetic parameters of marbofloxacin like larger volume of distribution, optimum AUC and $\mathrm{C}_{\max }$ make it a potentially useful drug for the treatment of genital tract, respiratory tract, gastrointestinal tract,

\footnotetext{
Author for correspondence: Dr. Harshad B. Patel

Assistant Professor, Department of Veterinary Pharmacology and Toxicology, College of Veterinary Science and Animal Husbandry, Junagadh Agricultural University, Junagadh-362001, Gujarat, India E-mail: harshadvet@gmail.com

Tel.: +91-9558514761
}

Copyright @ 2018 Ukaaz Publications. All rights reserved.

Email: ukaaz@yahoo.com; Website: www.ukaazpublications.com skin and soft tissue infections in domestic animals and birds (Brown, 1996; Ihrke et al., 1999). Along with higher efficacy, marbofloxacin is one of the safer floroquinolone compound as it did not produce any adverse reactions and significant alterations in biochemical and hematological parameters in rats after repeated intramuscular administration (Chauhan et al., 2017).

Pharmacokinetics of marbofloxacin after single oral administration in various animal species and birds revealed its poor oral bioavailability, which limits its therapeutic effectiveness. Pharmacokinetics of marbofloxacin following repeated oral administration have been conducted in cats (Albarellos et al., 2005) and rabbits (Carpenter et al., 2009). Pharmacokinetics of marbofloxacin after repeated oral administration in broiler chickens were not studied earlier. Hence, present study was planned to investigate the pharmacokinetics of marbofloxacin following single $(5 \mathrm{mg} / \mathrm{kg}$ ) and repeated dose (5 mg/kg, for 5 days) oral administration in broiler chickens to generate valuable information for designing effective dosage regimen for long term oral administration.

\section{Materials and Methods}

\subsection{Approval of project by ethics committee}

The study protocol was approved by Institutional Animal Ethics Committee (IAEC), College of Veterinary Science and A. H., JAU, Junagadh (Protocol No.: JAU/JVC/IAEC/SA/22/2017 dated: 26/05/ 2017). 


\subsection{Experimental animals}

The pharmacokinetics of the drug after single and repeated administration was carried out on six broiler chickens (same set of animals) of strain 'Cobb 400' which were obtained from Venky's India Ltd. (Division of Narmada Hatcheries), Anand, Gujarat. Birds were maintained as per CPCSEA guidelines for laboratory animal facility (CPCSEA, 2003). Initially, day old chicks were maintained with twenty four hour light with brooder for one week in broiler house and reared up to the age of 3 weeks and vaccination schedule was followed as per standard managemental practices to control common infectious diseases of birds. During entire study period, the broiler chickens were housed in the cool environment of winter season of 20 to $30^{\circ} \mathrm{C}$ temperature and with relative humidity ranged between 40 to $55 \%$. Broiler starter and finisher feed of BIS (98621992) specification (Simran Feeds Pvt. Ltd, Indore, Madhya Pradesh, India) and reverse osmosis drinking water was provided ad libitum to chickens. All broiler chickens were randomly selected for the study.

\subsection{Drugs and chemicals}

Technical grade pure marbofloxacin powder was procured from Sigma Aldrich, Bangalore, India. Marbofloxacin tablet $50 \mathrm{mg}$ (Marbomet $^{\circledR}$ ) (Intas Pharmaceuticals Ltd., Ahmedabad, India) was used for oral administration to broiler chickens. Water, acetonitrile, per chloric acid and formic acid of HPLC grade were purchased from Merck India Ltd., Mumbai.

\subsection{Experimental design}

Six broiler chickens of 3 weeks of age were administered with marbofloxacin $(5 \mathrm{mg} / \mathrm{kg}$ ) through oral gavazing needle (16 G x 4" bent feeding needles) for 5 consecutive days. Pharmacokinetic analysis was carried after first and fifth dose of marbofloxacin in six chickens only. Blood samples (approximately, $0.50 \mathrm{ml}$ ) were collected through IV catheter $(26 \mathrm{G} \mathrm{x} 3 / 4 ; 0.6 \times 0.19 \mathrm{~mm}$; flow $15 \mathrm{ml} /$ $\mathrm{min}$ ) fixed in wing vein in heparinized centrifuge tubes. Following oral administration of drug, at day $1^{\text {st }}$ and day $5^{\text {th }}$, blood samples were collected at $0 \mathrm{~min}$ (before drug administration) $5(0.0833 \mathrm{~h}$ ), $10(0.1667 \mathrm{~h}), 15(0.25 \mathrm{~h})$ and $30(0.5 \mathrm{~h}) \mathrm{min}$ and at $1,2,4,8,12$ and $24 \mathrm{~h}$. Plasma was separated after centrifugation of each blood sample at $12000 \mathrm{rpm}$ for $10 \mathrm{~min}$ at $4^{\circ} \mathrm{C}$ (Eppendorf $5430 \mathrm{R}$, Germany) and transferred to cryo-vial ( $2 \mathrm{ml}$ capacity) and then stored at $-85^{\circ} \mathrm{C}$ until assayed for marbofloxacin concentration using HPLC.

\subsection{HPLC analysis}

\subsubsection{Chromatographic condition}

The plasma samples were analyzed for marbofloxacin concentration with minor modifications in method described by Carpenter et al. (2006). The HPLC apparatus (LC-2010 CHT) of Schimadzu, Japan, comprising quaternary gradient delivery pump (LC-2010) with UV detector was used for assay. Chromatographic separation was carried out using reverse phase Zorbax XDB-C ${ }_{18}$ analytical column (4.6 $\mathrm{mm} \times 250 \mathrm{~mm}$; ID $5 \mu$ ). The mobile phase was a mixture of $10 \mathrm{mM}$ formic acid in HPLC water and acetonitrile (80:20) which was filtered by $0.45 \mu \mathrm{m}$ size filter (Millipore India Pvt., Ltd., Bangalore) and degassed by ultra-sonication. The mobile phase was pumped into column at a flow rate of $0.75 \mathrm{ml} / \mathrm{min}$ with column oven temperature of $30^{\circ} \mathrm{C}$. The effluent was monitored at $295 \mathrm{~nm}$ wavelength.

\subsubsection{Extraction of plasma samples}

Deproteinization of each plasma sample $(250 \mu \mathrm{l})$ was done by precipitation with addition of $250 \mu 1$ of perchloric acid $(0.8 \mathrm{M})$. Mixture was vortexed for $10 \mathrm{~min}$, followed by centrifugation at $12000 \mathrm{rpm}$ for $10 \mathrm{~min}$. Clear supernatant was collected in to HPLC vials and $20 \mu \mathrm{l}$ of sample was injected in to HPLC system through auto injector. The HPLC data integration was performed using LC solution software (Shimadzu).

\subsubsection{Method validation}

For standardization, initially stock solution of marbofloxacin was prepared by dissolving $1 \mathrm{mg}$ pure form of marbofloxacin (Sigma Aldrich) in $1 \mathrm{ml}$ HPLC water. The stock solution of drug was diluted with drug-free poultry plasma to prepare standard marbofloxacin concentrations of $0.049,0.097,0.195,0.391,0.781$, $1.563,3.125,6.25,12.5,25.0$ and $50.0 \mu \mathrm{g} / \mathrm{ml}$. Quantification of marbofloxacin in plasma samples was done by reference to the resultant standard curve (Figure 1). Chromatographic separation of marbofloxacin from plasma standard $(6.25 \mu \mathrm{g} / \mathrm{ml})$ is shown in (Figure 2 ). The assay was sensitive and reproducible, and linearity was observed from 0.049 to $50 \mu \mathrm{g} / \mathrm{ml}$ with mean correlation coefficient (r) $>0.999$. The lower limit of quantification of the drug was 0.049 $\mu \mathrm{g} / \mathrm{ml}$ with a coefficient of variation of less than $9.43 \%$.

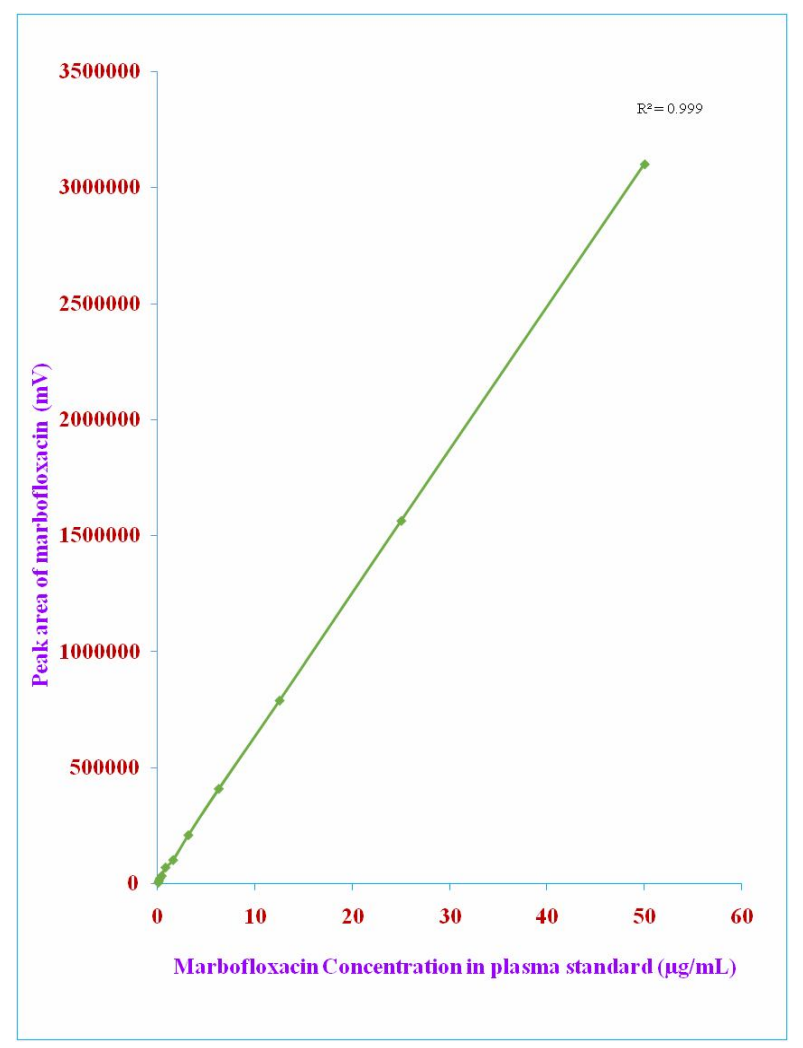

Figure 1: Standard curve of marbofloxacin in drug free plasma of broiler chickens. 


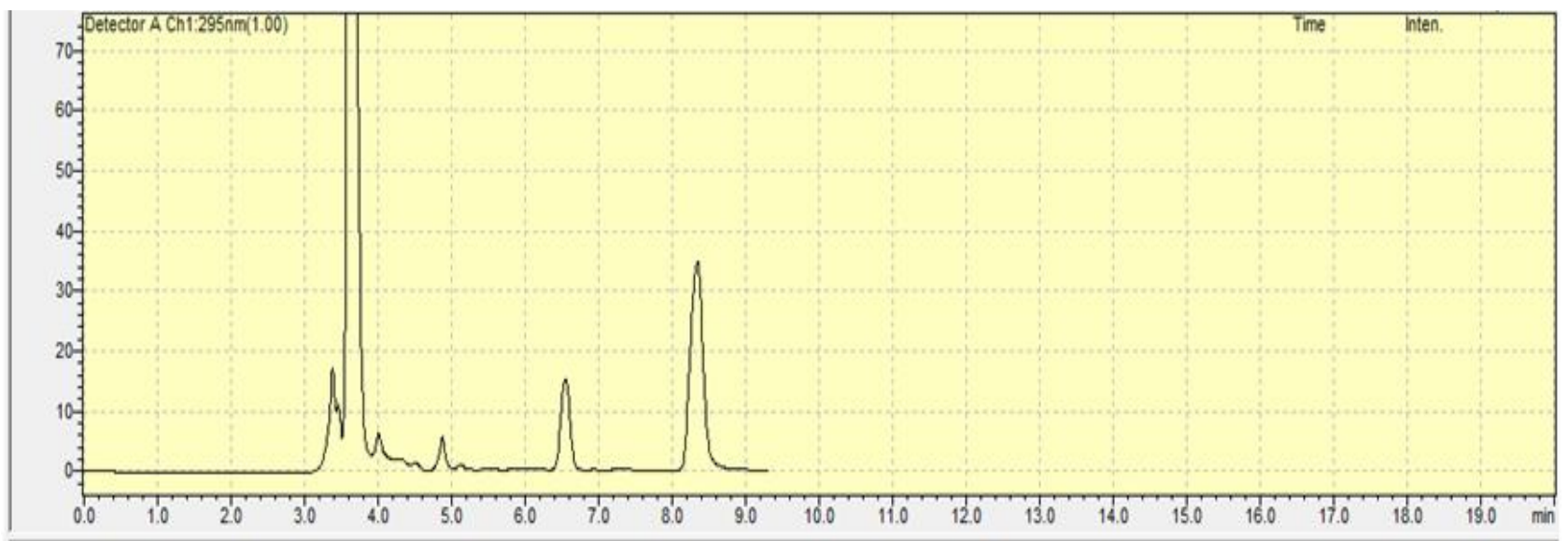

Figure 2: Chromatographic separation of marbofloxacin from plasma standard $(6.25 \mu \mathrm{g} / \mathrm{ml})$ with retention time of $8.0 \pm 0.2 \mathrm{~min}$.

\subsection{Pharmacokinetic analysis}

Pharmacokinetic parameters were calculated as per standard methods (Baggot, 1977; Gibaldi and Perrier, 1982). A': Zero-time intercept of absorption phase and B: Zero-time intercept of elimination phase were calculated by the method of residual yields, $\mathrm{K}_{\mathrm{a}}$ : Absorption rate constant and $\beta$ : Elimination rate constant were calculated by least square regression analysis method, $\mathrm{t}_{1 / 2 \mathrm{k}}$ : Absorption half-life $\left(0.693 /{ }_{\mathrm{ka}}\right), \mathrm{t}_{1 / 2 \beta}$ : Elimination half-life $(0.693 /$ $\beta), \mathrm{C}_{\max }$ : Maximum drug concentration in plasma and $\mathrm{T}_{\max }$ : Time of maximum observed concentration in plasma were calculated from actual plasma concentrations of each broiler chicken, AUC: Area under the curve and AUMC: area under the first moment of curve were calculated by linear trapezoidal rule, $\mathrm{Vd}_{(\text {area }}$ : Apparent volume of distribution (Dose $\times \mathrm{F}) /(\beta \times \mathrm{AUC}), \mathrm{Vd}_{(\mathrm{ss})}$ :Volume of distribution at steady state (Dose $\mathrm{x}$ AUMC)/( $\left.\mathrm{AUC}^{2}\right), \stackrel{\mathrm{Ss}}{\mathrm{C}} \mathrm{B}_{\mathrm{B}}$ : Total body clearance $\left(\beta \times \mathrm{Vd}_{\text {(area) }}\right)$, MRT: Mean residence time (AUMC/AUC), F: Bioavailability (Dose i.v. x AUC p.o)/(Dose p.o. x AUC i.v.). were calcualted as per standard formula.

\subsection{Statistical analysis}

The data obtained for pharmacokinetic parameters were presented as Mean \pm S.E. and analyzed statistically using paired sample t-test. The levels of significance to observe difference were 0.05 and 0.01 . The $p$ values $<0.05$ or $<0.01$ were considered as statistically significant or highly significant, respectively.

\section{Results and Discussion}

The plasma concentrations $(\mu \mathrm{g} / \mathrm{ml})$ of marbofloxacin in relation to time in broiler chickens following single $(5 \mathrm{mg} / \mathrm{kg}$ ) and repeated dose oral administration $(5 \mathrm{mg} / \mathrm{kg}$, daily for 5 days) are presented in Table 1 and semilogarithmic plot of the same is shown in Figure 3. Following oral administration, the plasma concentrations at 0.0833 $\mathrm{h}(5 \mathrm{~min})$ were $0.45 \pm 0.08$ and $0.50 \pm 0.08 \mu \mathrm{g} / \mathrm{ml}$ after single and repeated administration, respectively. The plasma concentration at 30 min after single oral administration was $1.69 \pm 0.20 \mu \mathrm{g} / \mathrm{ml}$ which was significantly $(p<0.05)$ higher than the respective value of 1.34 $\pm 0.23 \mu \mathrm{g} / \mathrm{ml}$ after repeated administration.

Following single and repeated oral administration of marbofloxacin, peak plasma concentrations $\left(\mathrm{C}_{\max }\right)$ of $2.05 \pm 0.23$ and $1.81 \pm 0.25$ $\mu \mathrm{g} / \mathrm{ml}$, respectively were observed at $\left(\mathrm{T}_{\max }\right) 0.83 \pm 0.11$ and $1.50 \pm$ $0.22 \mathrm{~h}$, respectively. The $\mathrm{C}_{\max }$ and $\mathrm{T}_{\max }$ values after single and repeated oral administration of marbofloxacin were non-significantly different. Patel et al. (2011) reported lower $\mathrm{C}_{\max }$ value of $1.74 \pm$ $0.02 \mu \mathrm{g} / \mathrm{ml}$ at $2 \mathrm{~h}$ after single oral administration of gatifloxacin in white leg horn layer birds. Similarly, after single oral administration of ciprofloxacin $(10 \mathrm{mg} / \mathrm{kg})$, lower peak plasma drug concentration $\left(\mathrm{C}_{\max }\right)$ of $1.12 \pm 0.18 \mu \mathrm{g} / \mathrm{ml}$ was observed at $0.67 \pm 0.12 \mathrm{~h}$ in rats (Devi et al., 2016). However, after six days, repeated oral administration of marbofloxacin in cats, higher value of $\mathrm{C}_{\max }(2.34 \pm$ $0.98 \mu \mathrm{g} / \mathrm{ml}$ at $1.60 \pm 1.20 \mathrm{~h}$ ) was observed as compare to respective value of $\mathrm{C}_{\max }(1.78 \pm 0.53 \mu \mathrm{g} / \mathrm{ml}$ at $1.61 \pm 1.80 \mathrm{~h})$, following single dose of drug (Albarellos et al., 2005). Carpenter et al. (2009) also reported higher $\mathrm{C}_{\max }$ value of $2.56 \pm 0.71 \mu \mathrm{g} / \mathrm{ml}$ at $1.40 \pm 0.44 \mathrm{~h}$ in rabbits after repeated oral administration for 10 days as compare to respective value of $1.73 \pm 0.35 \mu \mathrm{g} / \mathrm{ml}$ at $1.60 \pm 0.94 \mathrm{~h}$ after single dose.

Table 1: Comparison of plasma concentrations of marbofloxacin following single $(5 \mathrm{mg} / \mathrm{kg})$ and repeated dose $(5 \mathrm{mg} / \mathrm{kg}$ for 5 days) dose oral administration in broiler chickens $(n=6)$

\begin{tabular}{|c|c|c|}
\hline \multirow{2}{*}{$\begin{array}{c}\text { Time after drug } \\
\text { administration } \\
(\mathrm{h})\end{array}$} & \multicolumn{2}{|c|}{ Plasma concentrations $(\mu \mathrm{g} / \mathrm{ml})$} \\
\cline { 2 - 3 } & $\begin{array}{c}\text { Marbofloxacin } \\
\text { single dose }\end{array}$ & $\begin{array}{c}\text { Marbofloxacin } \\
\text { repeated dose }\end{array}$ \\
\hline 0.0833 & $0.45 \pm 0.08$ & $0.50 \pm 0.08$ \\
\hline 0.1667 & $1.13 \pm 0.24$ & $0.88 \pm 0.20$ \\
\hline 0.25 & $1.45 \pm 0.22$ & $1.03 \pm 0.23$ \\
\hline 0.5 & $1.69 \pm 0.20$ & $1.34 \pm 0.23 *$ \\
\hline 1 & $2.00 \pm 0.23$ & $1.65 \pm 0.21$ \\
\hline 2 & $1.68 \pm 0.18$ & $1.68 \pm 0.29$ \\
\hline 4 & $1.16 \pm 0.17$ & $1.29 \pm 0.17$ \\
\hline 6 & $0.90 \pm 0.18$ & $0.96 \pm 0.13$ \\
\hline 8 & $0.67 \pm 0.18$ & $0.68 \pm 0.08$ \\
\hline 12 & $0.38 \pm 0.06$ & $0.43 \pm 0.07$ \\
\hline 24 & $0.08 \pm 0.01$ & $0.14 \pm 0.03$ \\
\hline
\end{tabular}

Values are expressed as Mean \pm SEM

* Significant $(p<0.05)$; ** highly significant $(p<0.01)$ difference between single and repeated administration 


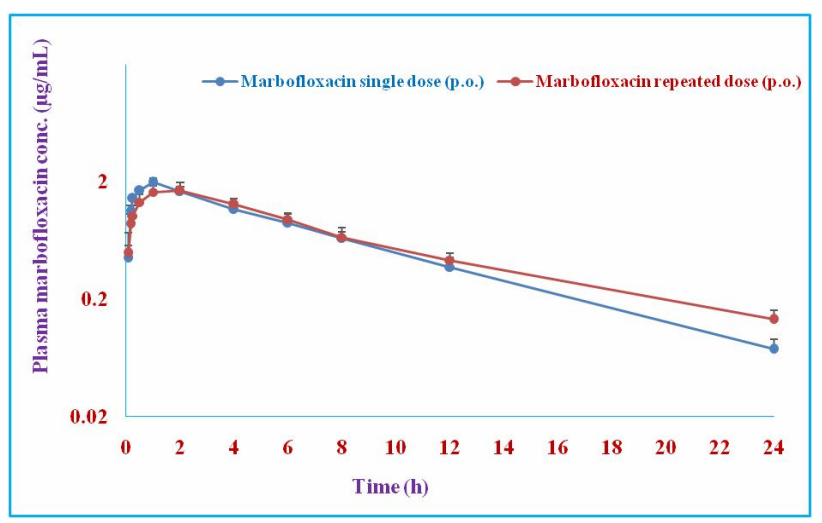

Figure 3: Semilogarithmic plot of marbofloxacin concentration in plasma versus time following single $(5 \mathrm{mg} / \mathrm{kg})$ and repeated dose $(5 \mathrm{mg} / \mathrm{kg}$, for 5 days) oral administration in broiler chickens.

The plasma concentrations of marbofloxacin of $\geq 0.38 \pm 0.06$ (after single dose) and $\geq 0.43 \pm 0.07 \mu \mathrm{g} / \mathrm{ml}$ (after repeated dose) were maintained up to $12 \mathrm{~h}$ after drug administration. The plasma concentrations at $12 \mathrm{~h}$ in both cases were found higher than reported range of minimum inhibitory concentration $\left(\mathrm{MIC}_{90}\right)$ value of 0.125 $0.20 \mu \mathrm{g} / \mathrm{ml}$ against $E$. coli and other Gram-negative bacterial infections in chickens and turkeys (Spreng et al., 1995; Haritova et al., 2006).

Table 2: Comparison of pharmacokinetic parameters of marbofloxacin following single $(5 \mathrm{mg} / \mathrm{kg})$ and repeated dose $(5 \mathrm{mg} / \mathrm{kg}$ for 5 days) dose oral administration in broiler chickens $(n=6)$

\begin{tabular}{|c|c|c|c|}
\hline $\begin{array}{c}\text { Pharmacokinetic } \\
\text { parameters }\end{array}$ & Unit & $\begin{array}{c}\text { Marbofloxacin } \\
\text { single dose }\end{array}$ & $\begin{array}{c}\text { Marbofloxacin } \\
\text { repeated dose }\end{array}$ \\
\hline $\mathrm{A}^{\prime}$ & $\mu \mathrm{g} / \mathrm{ml}$ & $2.07 \pm 0.15$ & $1.75 \pm 0.29$ \\
\hline $\mathrm{B}$ & $\mu \mathrm{g} / \mathrm{ml}$ & $2.22 \pm 0.23$ & $2.05 \pm 0.30$ \\
\hline $\mathrm{K}_{\mathrm{a}}$ & $\mathrm{h}^{-1}$ & $3.84 \pm 0.80$ & $2.29 \pm 0.30$ \\
\hline$\beta$ & $\mathrm{h}^{-1}$ & $0.16 \pm 0.01$ & $0.13 \pm 0.01$ \\
\hline $\mathrm{t}_{1 / 2 \mathrm{ka}}$ & $\mathrm{h}$ & $0.22 \pm 0.04$ & $0.34 \pm 0.07$ \\
\hline $\mathrm{t}_{1 / 2 \beta}$ & $\mathrm{h}$ & $4.62 \pm 0.42$ & $5.63 \pm 0.60$ \\
\hline $\mathrm{C}_{\mathrm{max}}$ & $\mu \mathrm{g} / \mathrm{ml}$ & $2.05 \pm 0.23$ & $1.81 \pm 0.25$ \\
\hline $\mathrm{T}_{\max }$ & $\mathrm{h}$ & $0.83 \pm 0.11$ & $1.50 \pm 0.22$ \\
\hline $\mathrm{AUC}_{(0-\infty)}$ & $\mu \mathrm{g} \cdot \mathrm{h} / \mathrm{ml}$ & $15.11 \pm 2.19$ & $16.49 \pm 1.88$ \\
\hline $\mathrm{AUMC}$ & $\mu \mathrm{g} \cdot \mathrm{h}^{2} / \mathrm{ml}$ & $106.00 \pm 17.21$ & $143.92 \pm 22.30$ \\
\hline $\mathrm{Vd}_{(\mathrm{area})}$ & $\mathrm{l} / \mathrm{kg}$ & $1.32 \pm 0.10$ & $1.61 \pm 0.21$ \\
\hline $\mathrm{Vd}_{(\mathrm{ss})}$ & $1 / \mathrm{kg}$ & $2.62 \pm 0.50$ & $2.95 \pm 0.58$ \\
\hline $\mathrm{Cl}_{(\mathrm{B})}$ & $1 / \mathrm{h} / \mathrm{kg}$ & $0.20 \pm 0.02$ & $0.20 \pm 0.02$ \\
\hline $\mathrm{MRT}$ & $\mathrm{h}$ & $7.03 \pm 0.33$ & $8.80 \pm 0.81$ \\
\hline $\mathrm{F}$ & $\%$ & $60.22 \pm 8.07$ & $64.55 \pm 7.95$ \\
\hline
\end{tabular}

Values are expressed as Mean \pm SEM

* Significant $(p<0.05)$; ** highly significant $(p<0.01)$ difference between single and repeated administration

The pharmacokinetic parameters of marbofloxacin after its single and repeated dose oral administration $(5 \mathrm{mg} / \mathrm{kg}$, daily for 5 days) in broiler chickens are presented in Table 2. Following oral administration of the drug, mean absorption rate constants $\left(\mathrm{K}_{\mathrm{a}}\right)$ after single and repeated doses were $3.84 \pm 0.80$ and $2.29 \pm 0.30$ $\mathrm{h}^{-1}$, respectively whereas mean absorption half-life $\left(\mathrm{t}_{1 / 2 \mathrm{ka}}\right)$ were $0.22 \pm 0.04$ and $0.34 \pm 0.07 \mathrm{~h}$, respectively. After repeated oral administration of marbofloxacin, mean value of $\mathrm{t}_{1 / 2 \mathrm{ka}}$ of $0.39 \pm 0.38$ h was reported in cats (Albarellos et al., 2005). In present study, lower $t_{1 / 2 \mathrm{ka}}$ value of marbofloxacin was observed which suggested that drug has rapid absorption rate after repeated oral administration in broiler chickens as compared to cats.

In present study, mean values of elimination half-lives $\left(\mathrm{t}_{1 / 2 \beta}\right)$ were $4.62 \pm 0.42$ and $5.63 \pm 0.60 \mathrm{~h}$ after single and repeated dose, respectively. Carpenter et al. (2009) observed lower value of $t_{1 / 2 \beta}$ of $3.90 \pm 0.00 \mathrm{~h}$ in rabbits after repeated oral administration of marbofloxacin. Whereas, higher value of $\mathrm{t}_{1 / 2 \beta}$ of $7.77 \pm 0.31 \mathrm{~h}$ was reported after repeated oral administration in cats (Albarellos et al., 2005). After 3 days of repeated intramuscular administration of marbofloxacin, high value of $\mathrm{t}_{1 / 2 \beta}$ of $6.27 \pm 2.80 \mathrm{~h}$ was also found in lactating cows (Schneider et al., 2004). Such lower $t_{1 / 2 \beta}$ values in broiler chickens might be due to comparatively high clearance rate as compared to cows and cats. Lower elimination half-life in birds also might be due to anatomical and functional differences of kidneys between birds and mammals, as in birds tubular reabsorption is very low or absent (Landoni and Albarellos, 2015). Other reasons may be variation in dose, duration of marbofloxacin treatment and blood collection time intervals.

The area under the plasma concentration time curve (AUC) is a basic and important pharmacokinetic parameter which is proportionate to systemic exposure to a drug and is used to calculate bioavailability, volume of distribution and clearance of drug. The mean area under curve (AUC), following single and repeated administration in broiler chickens were $15.11 \pm 2.19$ and $16.49 \pm$ $1.88 \mu \mathrm{g} . \mathrm{h} / \mathrm{ml}$, respectively. In contrast to this, higher values of AUC of $29.19 \pm 9.12 \mu \mathrm{g} . \mathrm{h} / \mathrm{ml}$ in cats were found (Albarellos et al., 2005). AUC has been found lower after repeated oral administration in broiler chickens as compared to cats, may be related to substantial first pass effect (Adams, 2001).

Volumes of distribution are proportionality constants between total amount of drug in the body and plasma concentrations. Volume of distribution $\mathrm{Vd}_{\text {(area) }}$ after single and repeated administration were $1.32 \pm 0.10$ and $1.61 \pm 0.21 \mathrm{l} / \mathrm{kg}$, respectively in broiler chickens. Mean values of $\mathrm{Vd}_{\text {(area) }}$ were non-significantly different after single and repeated administration. However, earlier study reported low value of $\mathrm{Vd}_{\text {(area) }}$ of $0.96 \pm 0.24 \mathrm{l} / \mathrm{kg}$ in cats (Albarellos et al., 2005) as compared to the present study. The marbofloxacin has large volume of distribution in chickens compared to cats, which indicates extensive penetration of the drug in the body of broiler chickens after repeated oral administration.

Fluoroquinolones are excreted by renal, biliary or hepatic metabolic pathways. Renal tubular secretion is the major process involved in urinary excretion of drugs (Neuman, 1988). Marbofloxacin is excreted as unchanged form in the urine up to $40 \%$ of total administered drug in dogs (Schneider et al.,1996) and $30 \%$ in broiler chickens (Anadon et al., 2002). Following single and repeated oral administration of marbofloxacin, the total body clearance $\left(\mathrm{Cl}_{\mathrm{B}}\right)$ values were similar. The mean residence time (MRT) after single and repeated administrations were $7.03 \pm 0.33$ and $8.80 \pm 0.81 \mathrm{~h}$, respectively. We also evaluated pharmacokinetic profile of 
marbofloxacin in broiler chickens following single and repeated intravenous administration (Patel et al., 2018). The values of AUC of the drug following i.v. administration were used to calculate bioavailability, following single and repeated oral administration of marbofloxacin in broiler chickens. The mean calculated bioavailabilities after single and repeated oral administration were $60.22 \pm 8.07$ and $64.55 \pm 7.95 \%$, respectively. However, after repeated oral administration, higher value of bioavailability (106.0 $\pm 37.0 \%$ ) was observed in cats (Albarellos et al., 2005). The MRT and bioavailability values were non-significantly increased after repeated oral administration which might be due to entero-hepatic recycling of marbofloxacin in broiler chickens.

It has been recognized that for concentration-dependent antibacterial agents, such as ûuoroquinolones, the $\mathrm{C}_{\max }$ /MIC and AUC/MIC ratio are the most important efficacy predictors. The ratio of $\mathrm{AUC} / \mathrm{MIC}_{90}$ should at least $100-125 \mathrm{~h}$ and $\mathrm{C}_{\max } / \mathrm{MIC}_{90}$ should be at least 8-10 for achieving maximum clinical cure, bactericidal effect and to prevent emergence of resistant organisms (Craig, 1998; Turnidge, 1999). Single dose oral administration of marbofloxacin $(5 \mathrm{mg} / \mathrm{kg})$ in broiler chickens have shown $\mathrm{AUC} / \mathrm{MIC}_{90}$ ratio of $302.20,151.10$ and 75.55 $\mathrm{h}$ and $\mathrm{C}_{\max } / \mathrm{MIC}_{90}$ ratio of $41.00,20.50$ and 10.25 at MIC values of $0.05,0.10$ and $0.20 \mu \mathrm{g} / \mathrm{ml}$, respectively. Similar to this, $\mathrm{C}_{\mathrm{max}} / \mathrm{MIC}_{90}$ and AUC/MIC ${ }_{90}$ ratio were of 8.00 and $99.00 \mathrm{~h}$, respectively, observed at MIC level of $0.25 \mu \mathrm{g} / \mathrm{ml}$ after oral administration of marbofloxacin in cats (Albarellos et al., 2005).

\section{Conclusion}

After single and repeated dose oral administration of marbofloxacin $(5 \mathrm{mg} / \mathrm{kg})$ in broiler chickens, therapeutic effective concentrations were maintained up to $12 \mathrm{~h}$ post drug administration, which were larger than the reported concentration range of $0.125-0.20 \mu \mathrm{g} / \mathrm{ml}$ $\left(\mathrm{MIC}_{90}\right)$ against $E$. coli and other Gram-negative bacteria isolated from birds. This suggested longer duration of action of marbofloxacin against susceptible bacterial infections in broiler chickens.

In present study, long elimination half-life, large volume of distribution and area under curve were observed after single and repeated oral administration of marbofloxacin in broiler chickens. These favorable pharmacokinetic profile suggested that drug has capacity to clear the deep seated bacterial infections in broiler chickens. After single oral administration of marbofloxacin, higher $\mathrm{C}_{\max } / \mathrm{MIC}_{90}$ and $\mathrm{AUC} / \mathrm{MIC}_{90}$ values were observed which indicates drug's efficacy for treatment of susceptible bacterial infections with maximum clinical cure in broiler chickens.

\section{Acknowledgments}

The authors are highly grateful to Junagadh Agricultural University, Junagadh, Gujarat, India for providing funds, research and animal facilities to undertake the research work.

\section{Conflict of interest}

We declare that we have no conflict of interest.

\section{References}

Adams, H. R. (2001). Pharmacokinetics: Disposition and fate of drugs in the body. "Veterinary Pharmacology and Therapeutics," $8^{\text {th }}$ Edn Iowa State University Press, Ames, Iowa, USA. pp:25.

Albarellos, G. A.; Montoya, L. and Landoni, M.F. (2005). Pharmacokinetics of marbofloxacin after single intravenous and repeat oral administration to cats. The Veterinary Journal, 170:222-229.
Anadon,A.; Martinez-Larranaga, M. R.; Diaz, M. J.; Martinez, M.A.; Frejo, M. T.; Martinez, M.; Tafur, M. and Castellano, V. J. (2002). Pharmacokinetic characteristics and tissue residues for marbofloxacin and its metabolite N-desmethyl-marbofloxacin in broiler chickens. American Journal of Veterinary Research, 63:927-933.

Baggot, J. D. (1977). Principles of drug disposition in domestic animals. The basis of veterinary clinical pharmacology. $1^{\text {st }}$ Ed., W.B. Saunders Co., Philadelphia, U.S.A., pp:144-189.

Brown, S. A. (1996). Fluoroquinolones in animal health. Journal of Veterinary Pharmacology and Therapeutics, 19:1-14.

Carpenter, J. W.; Hunter, R. P.; Olsen, J. H.; Henry, H.; Isaza, R. and Koch, D. E. (2006). Pharmacokinetics of marbofloxacin in blue and gold macaws (Araararauna). American Journal of Veterinary Research, 67(6): 947-950.

Carpenter, J. W.; Pollock, C. G.; Koch, D. E. and Hunter, R. P. (2009). Single and multiple-dose pharmacokinetics of marbofloxacin after oral administration to rabbits. American Journal of Veterinary Research,70 (4):521-526.

Chauhan, V. B.; Modi, C. M.; Patel, U. D.; Patel, H. B.; Kalaria, V. A.; Fefar, D. T.; Bhadarka, D. H.; Solanki, S. L. and Ahmed, S. R. (2017). Safety profile of marbofloxacin following repeated intramuscular administration alone and piperine pretreated rats. Ann. Phytomed., 6(2):88-92.

CPCSEA (2003). Committee for the Purpose of Control and Supervision on Experiments on Animals. Guidelines for laboratory animal facility. Indian Journal of Pharmacology, 35:257-274.

Craig, W. A. (1998). Pharmacokinetic/pharmacodynamic parameters: rationale for antibacterial dosing of mice and men. Clinical Infectious Diseases, 26:1-10.

Devi, K. K.; Srinu, B. and Rao, G. S. (2016). Effect of quercetin on the disposition kinetics of ciprofloxacin. Ann. Phytomed., 5(2):103107.

Drlica, K. and Zhao, X. (1997). DNA gyrase, topoisomerase IV, and the4quinolones. Microbiology and Molecular Biology Reviews, 61: 377-392.

Fitton, A. (1992). The quinolones. An overview of their pharmacology. Clinical Pharmacokinetics, 22:1-11.

Gibaldi, M. and Perrier, P. (1982). Noncompartmental analysis based on statistical moment theory. Pharmacokinetics. $2^{\text {nd }}$ ed. MarcelDekker Inc., New York, pp:409-417.

Haritova, A. M.; Rusenova, N. V.; Parvanov, P. R. ; Lashev, L. D. and, FinkGremmels, V. (2006). Integration of pharmacokinetic and pharmacodynamic indices of marbofloxacin in turkeys. Antimicrobial Agents and Chemotherapy, 50(11):3779-3785.

Ihrke, P. J.; Papich, M. G. and Demanuelle, T. C. (1999). The use of fluoroquinolones in veterinary dermatology. Veterinary Dermatology, 10:193204.

Jinukuti, M. G. and Giri, A. (2013). Antimicrobial activity of phytopharmaceuticals for prevention and cure of diseases. Ann. Phytomed., 2(2):28-46.

Landoni, M.F. and Albarellos, G. (2015). The use of antimicrobial agents in broiler chickens. The Veterinary Journal, 205:21-27.

Neuman, M. (1988). Clinical pharmacokinetics of the newer antibacterial 4-quinolones. Clinical Pharmacokinetics, 14:96-121.

Patel, H. B.; Patel, U. D.; Modi, C. M.; and Bhadarka, D. H. (2018). Pharmacokinetics of marbofloxacin following single and repeated dose intravenous administration in broiler chickens. International Journal of Current Microbiology and Applied Sciences, 7(6):23442351. 
Patel, S.; Devada, S.; Patel, H.; Patel, N.; Bhavsar, S. and Thaker, A. (2011). Influence of co-administration of piperine on pharmacokinetic profile of gatifloxacin in layer birds. Global Veterinaria,7(5):427432.

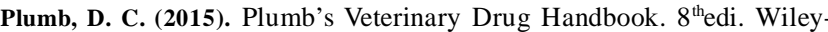
Blackwell, Iowa State University Press, Ames, Iowa, U.S.A., pp: 652-654.

Schneider, M.; Thomas, V.; Boisrame, B. and Deleforge, J. (1996) Pharmacokinetics of marbofloxacin in dogs after oral and parenteral administration. Journal of Veterinary Pharmacology and Therapeutics, 19(1):56-61.
Schneider, M.; Valle, M.; Woehrle', F. and Boisrame, B. (2004). Pharmacokinetics of marbofloxacin in lactating cows after repeated intramuscular administrations and pharmacodynamics against mastitis isolated strains. Journal of Dairy Science, 87:202-211.

Spreng, M.; Deleforge J.; Thomas, V.; Boisramé, B. and Drugeon, H. (1995). Antibacterial activity of marbofloxacin. A new fluoroquinolone for veterinary use against canine and feline isolates. Journal of Veterinary Pharmacology and Therapeutics, 18(4):284-289.

Turnidge, J. (1999). Pharmacokinetics and pharmacodynamics of fuoroquinolones. Drugs, 58:29-36. 